\title{
Environmental Culture and Nature in South Kalimantan Painting: An Overview of Fine Arts
}

\author{
Wisnu Subroto ${ }^{1 *}$ Hajriansyah $^{1}$ \\ ${ }^{I}$ Faculy of Teacher Training and Education, Lambung Mangkurat University, Indonesia \\ ${ }^{*}$ Corresponding author.Email: wisnusubroto@ulm.ac.id
}

\begin{abstract}
South Kalimantan painting has a long history, spanning from the early days of independence, with its character Gusti Sholihin Hasan, to the present day. The cultural atmosphere and natural environment of South Kalimantan have undoubtedly become objects in the works of South Kalimantan painters, from the past to the present, with the various styles of painting they have been pursuing. This research will focus on cultural objects related to the natural environment of South Kalimantan. The natural environment of South Kalimantan consists of at least the Meratus plateau and the banks of the Barito River and its branches. This study used a qualitative approach by directly reviewing the works of South Kalimantan painters that had been previously selected and classified. Through these works the conclusion is,
\end{abstract}

Keywords: The key to painting South Kalimantan, natural environment, cultural objects

\section{INTRODUCTION}

Modern painting in South Kalimantan began to grow since the beginning of independence, with Gusti Sholihin Hasan as the pioneering figure. From Sholihin came a regeneration of South Kalimantan painters, both those who later continued their academic studies in Java, or those who developed themselves self-taught [1]. According to Misbach Tamrin, Sholihin's painting teaching method, apart from delivering theoretical exposures, also invites his students to paint together outside or in the field. This method not only emphasizes the importance of direct observation of the object of the painting, but also so that (prospective) painters feel an atmosphere that will lead to feelings of empathy for the environment.

Painting in nature is a method that has long been practiced in the West. The English landscape painters (naturalists) and the Barbizon group in France painted directly outside the studio (in nature), because it was facilitated by the development of the means of production. Paints in tube packaging that were more practical to take out were invented and produced in the year 1840. These painterssuch as John Constable (1837) and JMW Turner (1851) from England, and Jean-Francois Millet (1875) and JeanBaptiste Camille Corot (1875) of France-shouldered his painting tools into nearby fields and forests to find pure objects still abundant in sunlight, to be painted in person [2].

Impressionist painters came after the realism period of Courbet and Manet. Continuing what naturalist painters, impressionist painters, who were still students at that time, painted directly outside the studio. They paint the river Seine, the parliament building, the train station, outdoor parties, horse races and various natural landscapes on the outskirts of Paris. Their paintings seem bathed in light, recording light particles falling on an object from time to time $[2,3]$.

In Indonesia, the painting movement outside the studio, in this realm, gained momentum after S. Soedjojono propagated it in an agitative way. He not only exemplified painting objects in nature, but also wrote with a revolutionary spirit, inviting young aspiring painters to be confident in their abilities [4]. This spirit also influenced the way of painting at that time, became a kind of tradition that Sholihin also exemplified to his students in the Tunas Pelukis Muda group.

The natural environment of South Kalimantan consists of the Meratus highlands and the Barito river valley. The Meratus Mountains divide the area of South Kalimantan into two, and to the south it is bordered by the Java Sea. The two main rivers in South Kalimantan are the Martapura river and the Negara river, both of which are tributaries of the Barito river which divides South Kalimantan and its upstream now enters the Central Kalimantan region in the Schwaner mountains, while its estuary ends in the Java Sea. The concentration of population settlements has always been found in riverbank areas, especially the banks of the Negara river and its subsidiaries which gave birth to the upstream community or the Banyu trunk, and the banks of the Martapura river and its branches which gave birth to the kuala community. These two groups of people, both upstream and kuala, live from farming and trading, by utilizing the river as a medium of transportation and a living. A small number of other people live in mountainous areas with farming and forest products [5,6,7].

This paper tries to examine some of the works of South Kalimantan painters, especially those with environmental themes, qualitatively. The first step, is to classify the types and thematic paintings related to the natural environment 
objects they paint. The second step reviews several works that are considered to represent their views on the natural environment in South Kalimantan, by borrowing a visual semiotic review and cultural studies $[8,9,10]$. The results of this review then concluded, what natural objects were the themes of the paintings of the South Kalimantan painters and how their views were immortalized through their works.

\section{DISCUSSION}

Nature painting does not only describe what is in nature in a naturalistic or realistic way. Philosophical and idealistic views see nature as the building block for human civilization. The philosophers of antiquity even saw that life was formed from elements that exist in nature, such as water and fire, for example. Along with the development of classical age thought and afterward, the view was then oriented towards humans as the main entity that thought and was able to produce civilization. Nature is seen as a resource that can be explored and exploited to build human civilization. Included in painting, where nature is then seen as idealistic and romantic. Ideally, natural structures are seen to be on the one hand eternal, as in the views of the neoclassical and cubistic painters. Meanwhile, on the other hand, romantically and in contemporary works, nature is considered to be increasingly eroded by the pace of civilization, modern technological advances that exploit life.

Like the Western painters, who influenced the development of modern painting in Indonesia in general and South Kalimantan in particular, who painted nature as an object that is beautiful and eternal, the South Kalimantan painters also made works with objects of the natural environment around them that were beautiful. and exotic. Even along with the development of tourism, natural objects of mountains and rivers and the dynamics of their people are explored for their exotic sides. Based on our research, paintings of natural landscapes (mountains) and rivers have become the object of most paintings by South Kalimantan painters. At least, nature has become the cultural background of the dynamics of the people who inhabit the areas along the river areas and mountainous landforms in South Kalimantan.

As far as our search on several photo collections of paintings obtained from exhibition catalogs that took place in Banjarmasin from 1999 to 2019, we have classified two models of painting objects with the theme of culture and the natural environment. The first is a natural landscape painting of the mountains and their forests, and the second describes the nature of the river and its people. We will explore further this natural painting of mountains and rivers, in relation to the views of South Kalimantan painters, through reviews of several works.

\subsection{Works of South Kalimantan painters}

\subsubsection{Misbach Tamrin painting}

Misbach Tamrin is a second-generation painter after Sholihin, who paints modernly on canvas and oil paint in South Kalimantan. Apart from being a painter, he also creates monuments in regencies / cities in South Kalimantan, including his works: the PKK monument at the Panin roundabout and the Pasar Antasari intersection in Banjarmasin; Taman Cahaya Bumi Selamat, Martapura (Banjar district), a horse monument on the bridge in the city of Rantau (Tapin district); relief diorama at the regent's office of Kandangan city (HSS district); hornbills monument in HST district; the monument to the struggle in Balangan district; etc [11].

Misbach was a direct student of Sholihin, who was a pioneer of modern art (painting) in South Kalimantan. He continued his studies at ASRI Yogyakarta at the encouragement of Sholihin, and later had a fairly large reputation in the Indonesian art scene. He is still actively working and participating in exhibitions until now. The painting discussed in this paper is "Mother Earth Menangis" (IPM), which is painted with oil on canvas as medium, with a size of $60 \times 120 \mathrm{~cm}$ and was made in 2011 . A photo of this painting is available in the catalog of the Selected Works Exhibition of the National Gallery of Indonesia and Artists. South Kalimantan with the theme Barito Sign, on July 7-14, 2011 at the Sari Citizen Building, Taman Budaya, South Kalimantan Province.

The IPM painting is made with realistic techniques and surrealistic nuances, capturing the massive deforestation of the $80-90 \mathrm{~s}$ in the Meratus forest area and the ecological impacts of drought and barren mountains, by taking the symbol of the motherland crying. This painting is made in three screens (parts), the background on the horizon depicting the Java sea, the middle background of the mountains of Meratus which looks parched, and the front which is filled with giant trees with logging activities below. There are depicted piles of logs from being cut down and trucks carrying logs. In the middle background, between the dry land and the rows of upright trees there is a green mound / hill that forms the figure of a mother breastfeeding her child lying on her side facing the viewer. Meratus mountain forest is symbolized through this figure which refers to the meaning of Mother Earth, or the land of birth. Through this painting, the painter's view of the land of his birth can be seen, in the form of bitterness and compassion for the damaged natural conditions caused by the massive logging of Meratus forest.

Likewise, what is seen in Misbach's other painting entitled "Save Meratus!", Oil on canvas, 90x150 cm, which was made in 2019. A photo of this painting is available in the catalog of the 2019 Kayuh Baimbai Grand Exhibition of Fine Arts, 20-26 September 2019. at Bigmall Samarinda, East Kalimantan. Horizontally depicted two parts of the Meratus mountains, on the left side of the green and beautiful nature and on the left side of the landscape which has been damaged by coal mining activities. In the middle, crossing the left and right, there is a portrait of a mother breastfeeding her child and below it is an orangutan mother holding her child in a desperate state. These two paintings have the same smell, concern for the destruction of nature due to human greed. 


\subsubsection{Rizal Noor's painting}

Rizali Noor is a third generation painter, after Misbach, who continued his fine arts studies in Yogyakarta. He had studied at the IKIP Yogyakarta Fine Arts Education, and after two years decided to move to STSRI-ASRI Yogyakarta (but did not finish). In the early 1980s he returned to Banjarmasin and worked at the South Kalimantan Cultural Park. Apart from painting, he also built a children's studio in what would become the Sholihin Workshop for the South Kalimantan Cultural Park. The style of painting is more or less influenced by the cheerfulness of the children in decorative nuances.

In his painting with the theme of the river, which was exhibited in his solo exhibition at the Sholihin Workshop from November 28 to December 28, 2018, Rizali Noor portrays the nuances of the riverside community in a naive-cubistic style. In this oil painting on canvas, he describes how the condition of the river in the city of Banjarmasin is getting narrower (and shallower) with the massive growth of buildings on the riverbanks. A river (with boating people and klotok) in the middle of the painting is seen curving between the concrete buildings on the left and right. Similar to the fact that the Martapura river today is in the middle of the city of Banjarmasin, where the left and right sides are massively paved with concrete. The concrete buildings are described as multistoried and on average they have domes, like to describe that Banjarmasin is the city of a thousand mosques. In a cheerful and religious atmosphere, which is constructed through naive colors and styling, apart from the religious atmosphere of the Banjar people, there is a nuance of concern over the loss of river culture which is increasingly displaced by land-oriented development.

\subsubsection{Painting of Umar Sidik and Steven}

Umar Sidik is a self-taught painter who has been diligently painting and exhibiting at the South Kalimantan Cultural Park since 2010. Previously, he worked as a screen printer and painter who peddled his paintings by the side of the road. Since the intensity of his work at Taman Budaya, especially at the Sholihin Workshop, he began to develop his painting techniques and ideas under the direction of the painter Zulian Rifani, who had studied at ISI Yogyakarta. His persistence and frequent participation in exhibitions on a national scale made his work more mature in terms of technicalities and ideas, he chose a realistic style with juxtaposition techniques (aligning objects in random compositions but interconnected contextually) which characterizes the present.

Her painting on the theme of traditional markets (floating markets) with the title "Pasar" (oil paint on canvas, $140 \times 120 \mathrm{~cm}, 2015)$, depicts the activity of a mother and a child buying fruit to an elderly mother with an odd river landscape as the background. The river is drawn without ripples of water, flat as foggy, but what characterizes it are the rows of jukung as usual on a floating market. In the foreground, shopping activities look colorful but stiff, while in the background the jukung-jukung moorings look cold and seem abandoned. Meanwhile, in another of his paintings, "Menatap" (oil paint on canvas, 130x145 cm, 2019), the face of an old man with local ornaments is seen staring into the distance. In the background, there is a coal mining activity with a factory building and an urban flyover in the background.

A similar nuance is depicted in the painting of Steven, a young painter who is still studying in Banjarmasin and learning to paint from painter Nanang M Yus, entitled "Save Bekantan" (oil on canvas, 90x120 cm, 2017). A proboscis monkey sits on a felled tree remnant, with a chainsaw resting on its side against an oblique cut of the tree, while flat under the logs of a sawn tree. Above it is a kind of virtual space arranged like a puzzle shape with a picture of a forest with trees and a pair of proboscis monkeys and their children sitting perched on two trees not far side by side. The virtual room has its puzzle removed by the side of a proboscis monkey sitting like a human beng brooding against a dark background. This painting portrays an irony similar to that of Umar's previous painting Menatap.

\subsubsection{Paintings of Akhmad Noor and Didi Agus}

Akhmad Noor is a South Kalimantan painter who has been painting since the 1990 s, but has only been actively painting and exhibiting since 2015, after previously living in Jakarta and working as a photographer and designer. He was born, grew up and lives until now on the banks of the Martapura river. Most of his life has been spent witnessing the growth of the city of Banjarmasin in the village on the banks of the Banua Anyar river. His paintings are in a realistic photographic style, capturing the life of the people on the banks of the Barito river and its branch of the Martapura river. Through the works entitled "Berlabuh" (oil paint on canvas, $75 \times 110 \mathrm{~cm}, 2016$ ) and "Going to School" (oil on canvas, $83 \times 120 \mathrm{~cm}, 2017$ ), you can see a beautiful river landscape. On the one hand, at Anchor, depicts the moorings of guide ships that used to tow coal barges;

If juxtaposed, the two paintings represent a paradox. On the one hand, the beautiful and melancholy atmosphere of the riverbanks, as well as the marginalization, while on the other hand it seems to describe the real "rulers" of the rivers in South Kalimantan, namely the rows of tug boats for coal barges. As illustrated by the actual situation, an irony that crosses the natural landscape of the river that supports the Banjar people.

Likewise, the same nuances of irony can be seen, through the paintings of Didi Agus, a painter who was born and grew up in Malang and moved to live in Banjarmasin, who has been actively working and exhibiting in the city of Banjarmasin since the early 2000s. His painting entitled "Semangat" (oil on canvas, 120x180 cm, 2017), captures a river landscape similar to that of Akhmad Noor's painting, where three children in school uniforms are rowing a boat. However, in this painting, it is depicted that a green border is replaced with a red and white background, which is the color of the Indonesian national flag. The cheerful faces of the children (pride) seem to describe the exoticism of the 
edge which is at the same time mixed with the atmosphere of being marginalized, while other urban children go to school through the smooth roads driven by vehicles.

\subsection{Transformation of Culture and Natural Environment}

Along with globalization, changes in the natural environment in South Kalimantan seem massive and very fast. The Meratus mountain area, for example, is illustrated by Damayanti's research[12]It seems that they are surrounded by a series of problems, especially those related to the natural environment and the socio-cultural changes of the people, which are intertwined with the rampant exploitation of natural resources in South Kalimantan.

Similar changes have also occurred downstream, in kuala, the location of the capital city of South Kalimantan, namely Banjarmasin, whose rivers are being eroded by developments that are increasingly land-oriented with tall and magnificent concrete buildings. The river environment and its people are increasingly marginalized, by paved roads which make mobility of people easier.

This change will undoubtedly bring a new culture and a different perspective from before. If nature was previously seen as the motherland, as in the romance of Misbach Tamrin's paintings, the mountainous and river landscape is now seen only as an exoticism which is beautiful and beautiful as well as being eroded by development. The rivers are tilted to make them look neat and attractive, as seen in Rizali Noor's painting, and the children on the riverbank become marginalized at the speed of vehicles on the highway. What remains are memories and irony, such as beauty juxtaposed with the marginalization of Akhmad Noor and Didi Agus' paintings. The local culture, which was once considered the high culture of civilized society in the highlands, remains a memory of being crushed by natural exploitation through massive-scale logging and mining, as in the painting of Umar Sidik. The condition gave birth to a psychological impact of "cultural shock" as felt by Damayanti when she saw Meratus' environment today. All new innate cultures from the advancement of civilization cause problems on the one hand, apart from progress with all its cultural instruments. This seems documented in the paintings of South Kalimantan painters today.

\section{CONCLUSION}

The natural environment of South Kalimantan consists of the Meratus mountain range and the Barito river and its branches. These two natural geographical conditions of the environment of South Kalimantan are recorded in the works of modern South Kalimantan painting, which have a history along with their growth at the national level since the beginning of Indonesian independence. In addition to making the surrounding environment the object of painting, these works also depict the culture of the people and the changes that have occurred in them.

The works of painters in South Kalimantan portray the natural environment around them not only as a beautiful natural reality. Their best paintings, from a technical perspective as well as ideas, which are the result of their learning and perseverance in following the discourse of global art, also portray the changing natural conditions. This change, which is the impact of development progress and the results of the exploitation of nature, brings a paradigm shift in seeing the natural environment and cultural transformations that occur in society. Their paintings not only depict beauty, but also a form of concern for changes and damage that occur in nature.

\section{REFERENCE}

[1] Hajriansyah, "The Four Periods of South Kalimantan Painting: A Historical Overview," $J$. Fine Art Galleries, vol. 4, no. 2, pp. 19-33, 2019.

[2] Soedarso, History of the Development of Modern Fine Arts. Jakarta: Studio Eighty, 2000.

[3] Diyanto, The Art of His Obsession. Bandung: Matahari, 2014.

[4] MA Burhan, Development of Mooi Indië Painting to Persagi in Batavia, 1900-1942. Jakarta: National Gallery of Indonesia, 2008.

[5] M. Suriansyah, Urang Banjar \& Culture. Jakarta: Waves, 2015.

[6] NH Radam, Hill People Religion. Yogyakarta: Semesta, 2001.

[7] A. David, Islam and Banjar Society: Description and Analysis of Banjar Culture. Jakarta: Raja Grafindo Persada, 1997.

[8] Kris Budiman, Visual Semiotics: Concept, Issue, and Problem Iconicity. Yogyakarta: Jalasutra, 2011.

[9] Susan Vihma \& Seppo Väkevä, Visual Semiotics and Product Semantics: An Introduction to Theory and Practice of Application of Semiotics in Design. Yogyakarta \& Bandung: Jalasutra, 2009.

[10] Arthur Asa Berger, Signs in Contemporary Culture: An Introduction to Semiotics. Yogyakarta: Tiara Wacana, 2005.

[11] Hairus Salim HS and Hajriansyah, Sailing in a Storm: Misbach Tamrin in the Art-Political Rumble. Yogyakarta: Ivory.

[12] D. Damayanti, Meratus, Singing Silence in the Mountains of Borneo. Yogyakarta: Lamera, 2016. 


\section{Attachment}

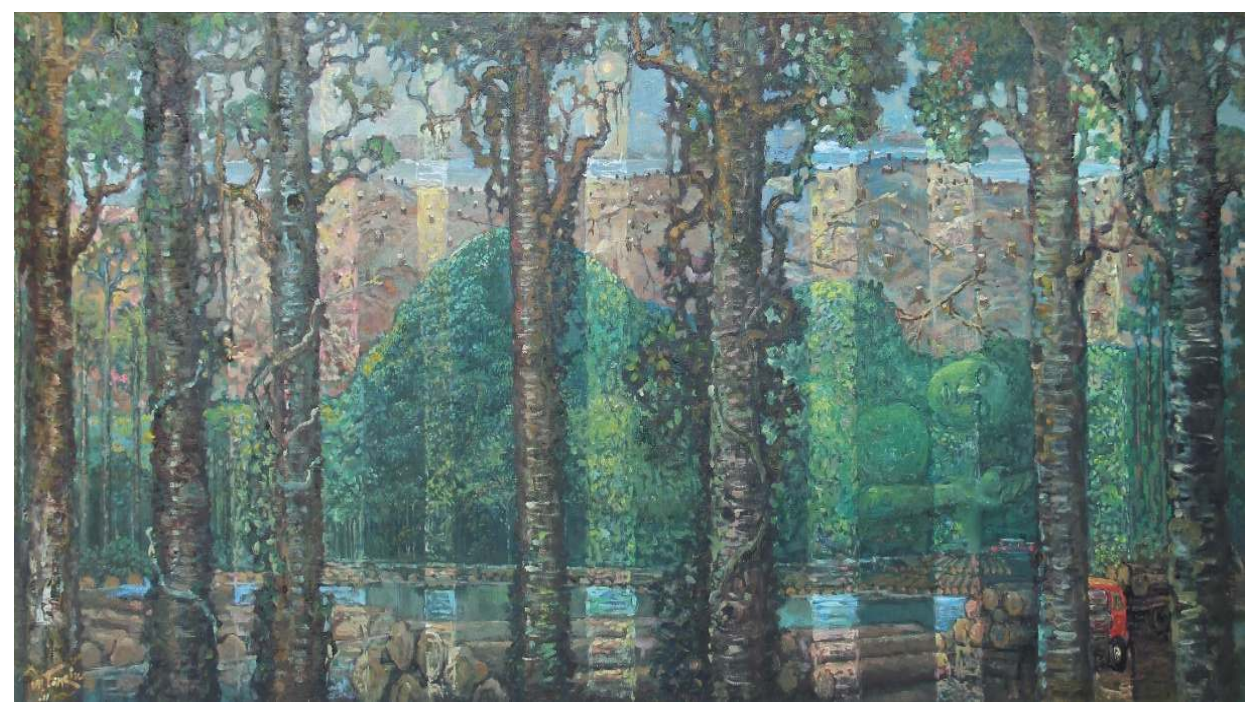

Misbach Tamrin, Ibu Pertiwi Menangis, Cat Minyak di Kanvas, 60x120 cm, 2011

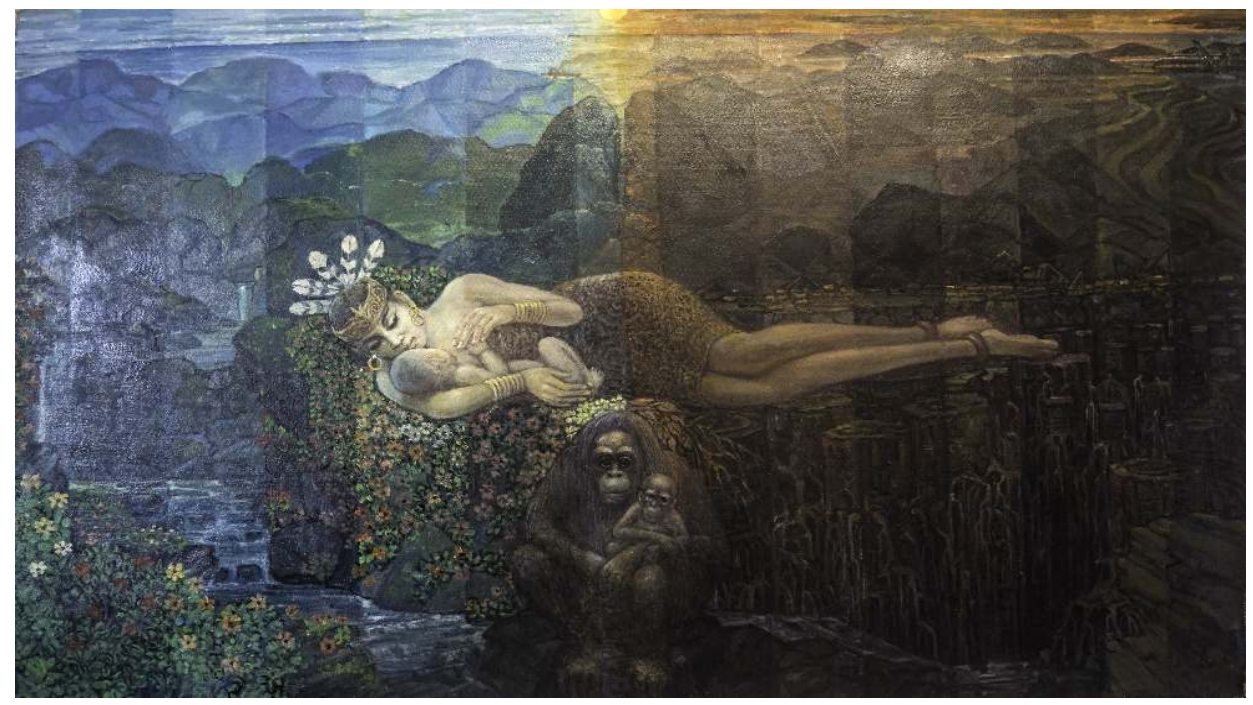

Misbach Tamrin, Save Meratus! Cat Minyak di Kanvas, 90x150 cm, 2019 


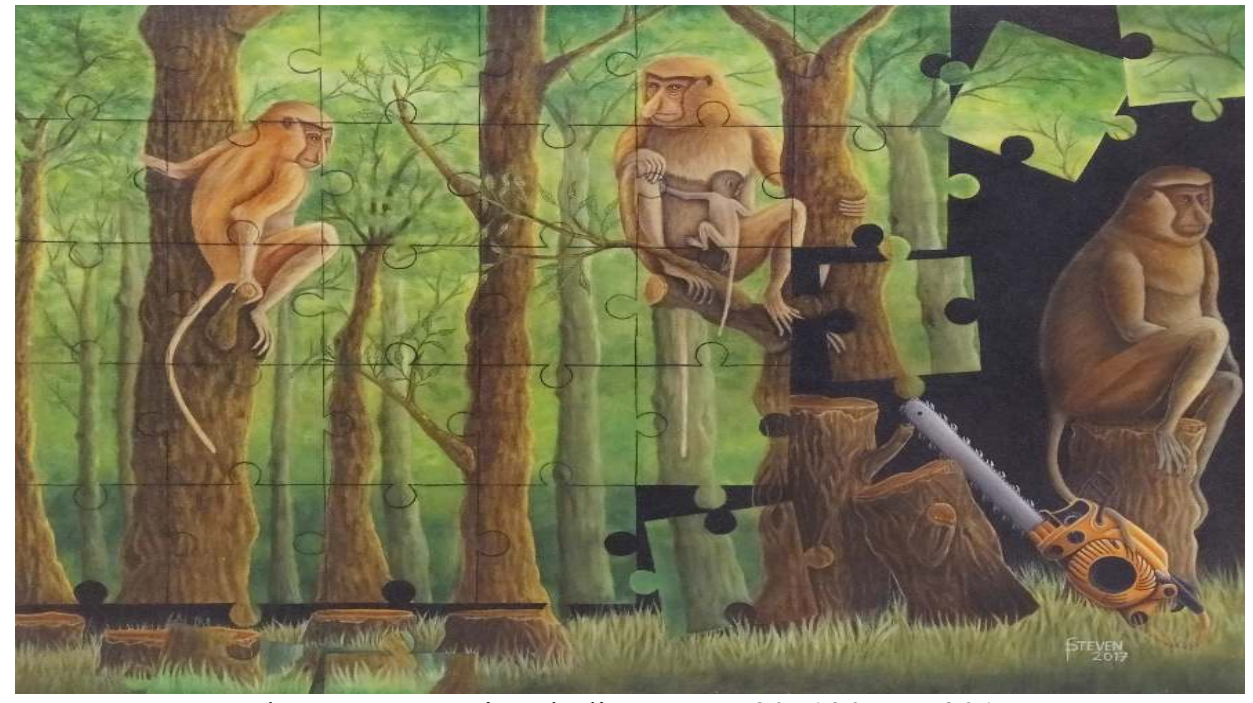

Steven, Save Bekantan, Cat Minyak di Kanvas, 90x120 cm, 2017

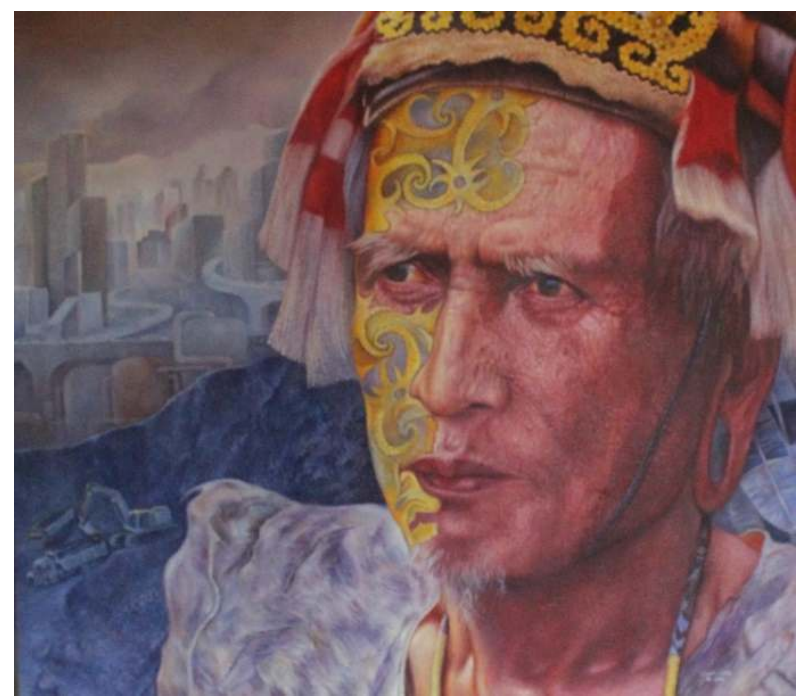

Umar Sidik, Menatap, Cat Minyak di Kanvas, 130x145 cm, 2019 


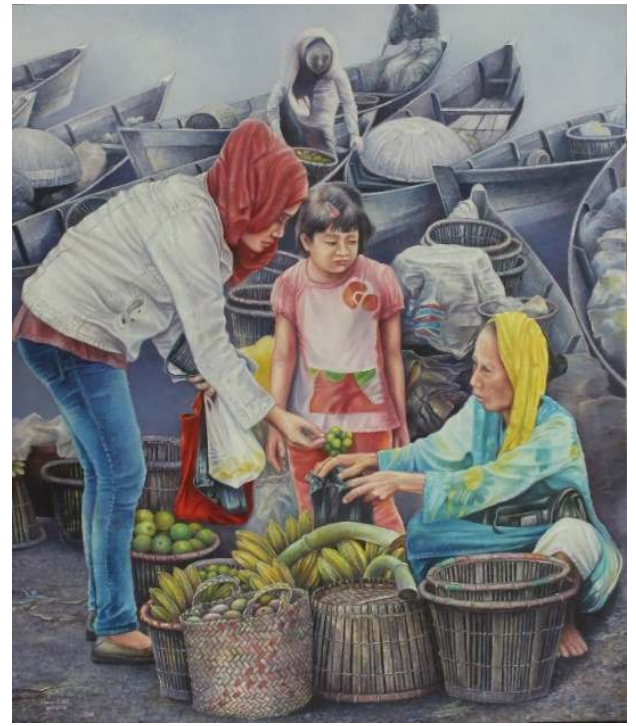

Umar Sidik, Pasar, Cat Minyak di Kanvas, 140x120 cm, 2015

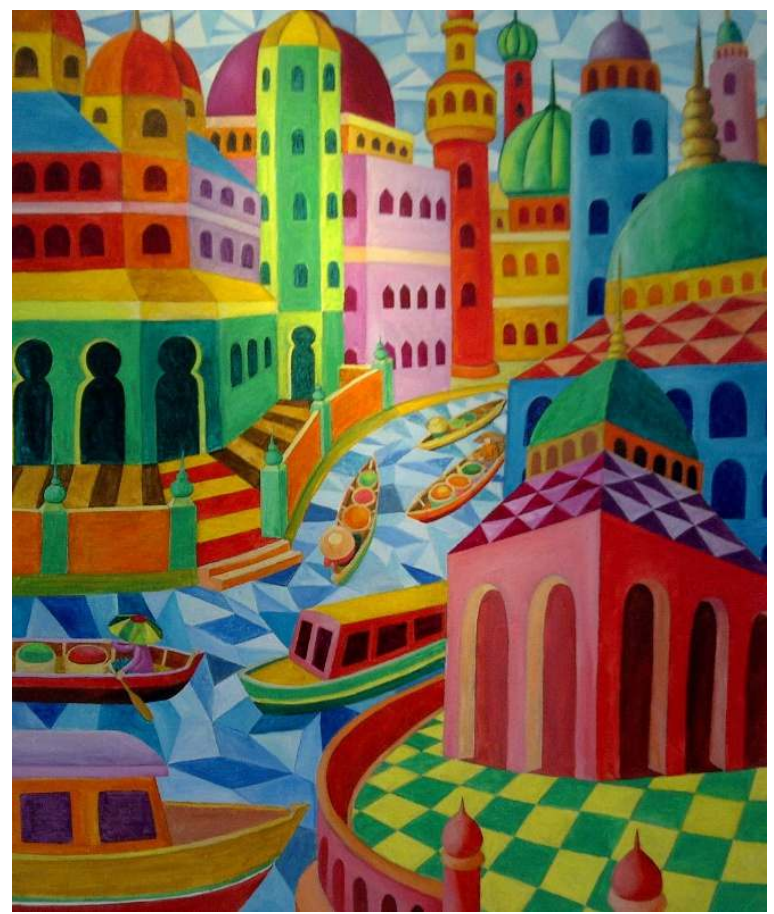

Rizali Noor, Seribu Sungai Seribu Masjid, Cat Minyak di Kanvas, 110x90 cm 


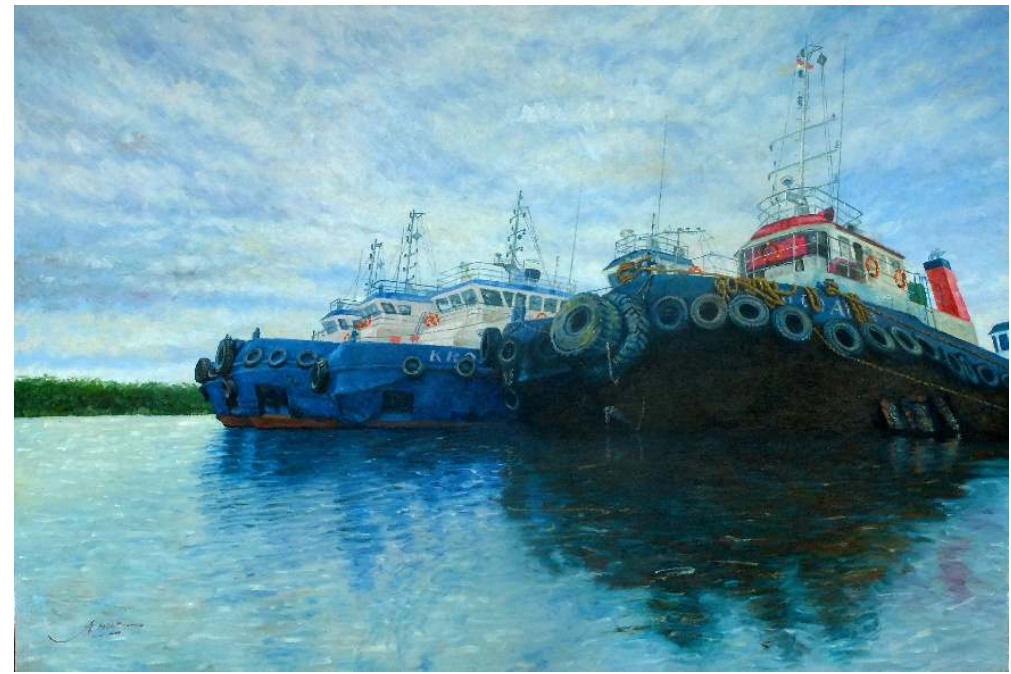

Akhmad Noor, Berlabuh, Cat Minyak di Kanvas, 75x110 cm, 2016

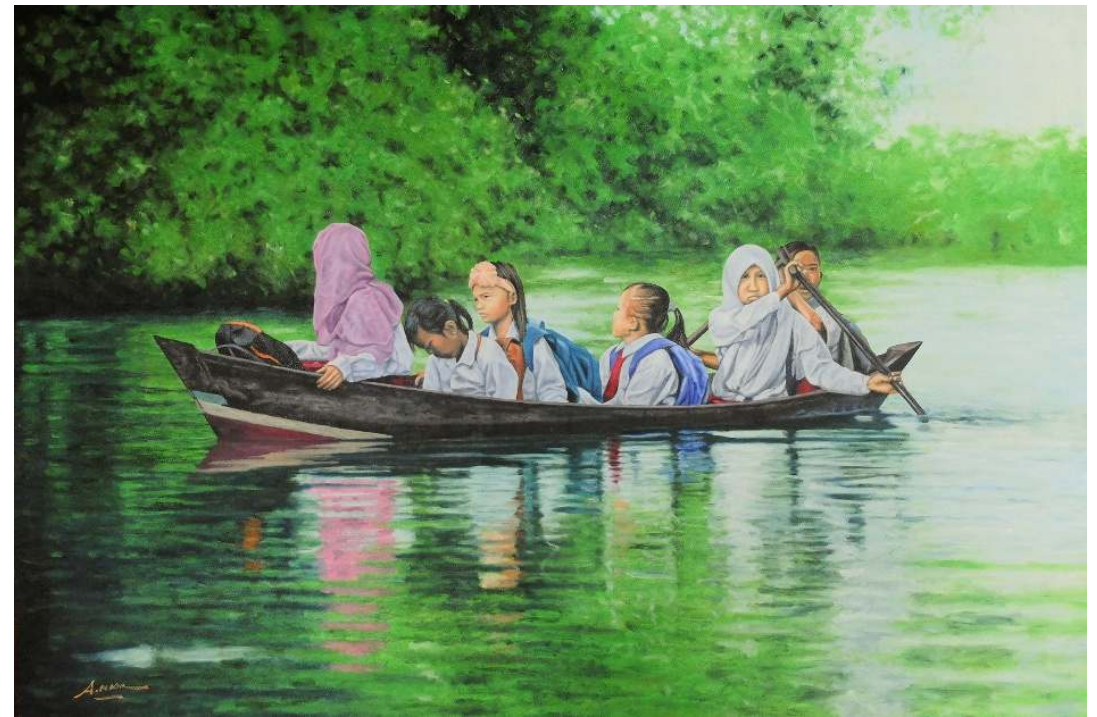

Akhmad Noor, Pergi ke Sekolah, Cat Minyak di Kanvas, 83x120 cm, 2017 


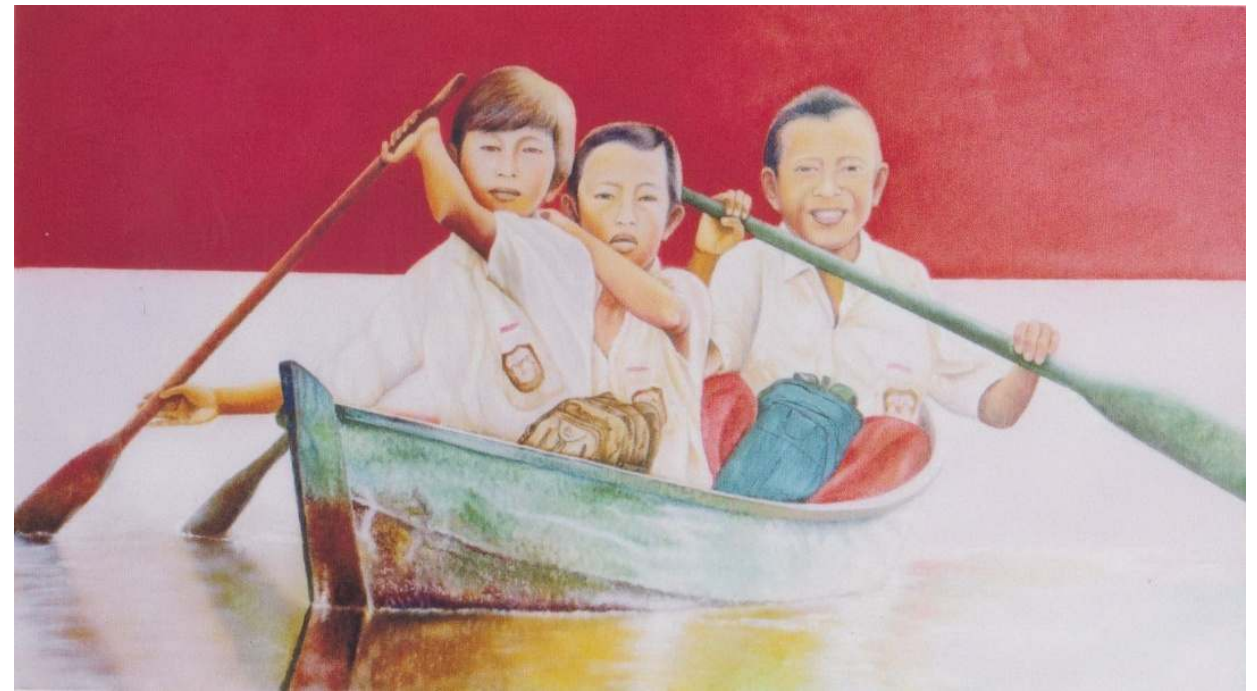

Didi Agus, Semangat, Cat Minyak di Kanvas, 120x180 cm, 2017 